\title{
A new and morphologically distinct population of cavernicolous Poecilia mexicana (Poeciliidae: Teleostei)
}

\author{
Tobler, M ; Riesch, R ; García de León, F J ; Schlupp, I ; Plath, M
}

\begin{abstract}
The cave molly, Poecilia mexicana, from the Cueva del Azufre, a sulfur cave in Tabasco, Mexico, ranks among the best-studied cave fishes worldwide, despite being known from a single population only. Here we describe a newly discovered second population of cave-dwelling P. mexicana from a nearby, but mostly non-sulfidic cave (Luna Azufre). Despite apparent similarities between the two populations (such as reduced eye diameter and reduced pigmentation), a geometric morphometric analysis revealed pronounced morphological differentiation between the two cave forms.
\end{abstract}

DOI: https://doi.org/10.1007/s10641-007-9258-x

Posted at the Zurich Open Repository and Archive, University of Zurich

ZORA URL: https://doi.org/10.5167/uzh-2507

Journal Article

Published Version

Originally published at:

Tobler, M; Riesch, R; García de León, F J; Schlupp, I; Plath, M (2008). A new and morphologically distinct population of cavernicolous Poecilia mexicana (Poeciliidae: Teleostei). Environmental Biology of Fishes, 82(1):101-108.

DOI: https://doi.org/10.1007/s10641-007-9258-x 


\title{
A new and morphologically distinct population of cavernicolous Poecilia mexicana (Poeciliidae: Teleostei)
}

\author{
M. Tobler $\cdot$ R. Riesch $\cdot$ F. J. García de León • \\ I. Schlupp $\cdot$ M. Plath
}

Received: 6 March 2007/Accepted: 19 April 2007/Published online: 23 May 2007

(C) Springer Science+Business Media B.V. 2007

\begin{abstract}
The cave molly, Poecilia mexicana, from the Cueva del Azufre, a sulfur cave in Tabasco, Mexico, ranks among the best-studied cave fishes worldwide, despite being known from a single population only. Here we describe a newly discovered second population of cave-dwelling $P$. mexicana from a nearby, but mostly non-sulfidic cave (Luna Azufre). Despite apparent similarities between the two populations (such as reduced eye diameter and reduced pigmentation), a geometric morphometric analysis revealed pronounced morphological differentiation between the two cave forms.
\end{abstract}

\footnotetext{
M. Tobler ( ()

Zoologisches Institut, Universität Zürich, Winterthurerstrasse 190, 8057 Zurich, Switzerland e-mail: tobler@ou.edu

M. Tobler · R. Riesch · I. Schlupp · M. Plath

Department of Zoology, University of Oklahoma, 730

Van Vleet Oval, Norman, OK 73019, USA

F. J. García de León

Centro de Investigaciones Biológicas del Noroeste, S.C., Mar Bermejo No. 195, Col. Playa Palo de Santa Rita, A.P. 128, La Paz, Baja California 23090, Mexico

M. Plath

Institut für Biochemie/Biologie, Abteilung für Evolutionsbiologie/Spezielle Zoologie, Universität Potsdam, Karl-Liebknecht-Str. 24-25, 14476 Potsdam, Germany
}

Keywords Cave fish - Cave molly - Extremophile · Hydrogen sulfide · Regressive evolution · Ecological diversification

\section{Introduction}

More than 100 species of teleost fishes permanently live in subterranean habitats (Proudlove 2006). Although the understanding of the diversity of hypogean fishes has increased steadily, the ecology and evolution of most species are still poorly examined, and detailed information is restricted to just a few systems (e.g., Poulson 1963; Strecker et al. 2003; Wilkens and Strecker 2003; Jeffery 2005).

One of the best studied cave fishes is the cave molly (Gordon and Rosen 1962), a distinct population of the Atlantic molly, Poecilia mexicana. The Atlantic molly is widespread in freshwater surface habitats along the Atlantic versant of Central America (Miller 2005). Compared to conspecifics from surface habitats, fish from the cave population have reduced albeit functional eyes and reduced pigmentation (Gordon and Rosen 1962; Walters and Walters 1965; Peters et al. 1973; Körner et al. 2006). Furthermore, cave mollies have reduced a set of behavioral traits, such as shoaling, aggression (Parzefall 1993), and the intensity of male sexual activity (Plath et al. 2003). On the other hand, cave mollies show a series of traits, most of which seem to improve communication and orientation in darkness 
and are absent in mollies from surface habitats. Female cave mollies exhibit a distinct genital pad that is absent in epigean fish. Supposedly, this pad secretes chemical cues that play a role during reproduction (Walters and Walters 1965; Zeiske 1968; Parzefall 1970, 1973) and are perceived by males during pre-mating behavior (nipping) utilizing the increased number of taste buds on their heads (Parzefall 1970). Furthermore, cave mollies exhibit a hyper-developed cephalic lateral line system (Walters and Walters 1965; Parzefall 2001), which has been documented to mediate spatial orientation in other cave fishes (Abdel-Latif et al. 1990; Burt de Perera 2004). On a behavioral level, cave mollies have evolved the ability to assess mate quality (such as the size or the nutritional state of mates) in darkness, whereas surface fish rely mainly on visual cues and are unable to assess mate quality in the absence of light (Plath et al. 2004, 2005).

The cave molly has only been reported from one cave, the Cueva del Azufre, in the state of Tabasco, Mexico (Gordon and Rosen 1962; Parzefall 2001). Its habitat is characterized not only by complete darkness (although some of the front cave chambers receive some light through openings in the ceiling), but also by high concentrations of hydrogen sulfide $\left(\mathrm{H}_{2} \mathrm{~S}\right)$ and hypoxic conditions (Gordon and Rosen 1962; Tobler et al. 2006). Hydrogen sulfide is a potent respiratory toxicant and is lethal for most metazoans even in micro-molar amounts (Bagarinao 1992; Grieshaber and Völkel 1998). Parzefall (2001) notes that the cave molly may have an increased $\mathrm{H}_{2} \mathrm{~S}$ tolerance, but generally the effects of $\mathrm{H}_{2} \mathrm{~S}$ on the evolutionary ecology of the cave molly are only poorly understood. A behavioral adaptation (aquatic surface respiration), by which fish exploit the oxygen-rich air-water-interface, seems to mediate the short-term survival of cave mollies in the toxic environment (Plath et al. submitted).
Recently, Pisarowicz (2005) reported the discovery of a new cave, the Luna Azufre, in the vicinity of the Cueva del Azufre that is also inhabited by a molly population. Mollies from both caves share characteristics such as reduced eyes and pigmentation (Fig. 1). Here we provide the first comparison of the newly discovered cave-dwelling population with fish from the Cueva del Azufre using geometric morphometrics. Furthermore, we present data from the first environmental survey comparing the two different habitats.

\section{Materials and methods}

Study sites

The caves studied are located near the village of Tapijulapa in Tabasco, Mexico. Cave mollies (males $N=6$; females $N=26$ ) were collected in the newly discovered Luna Azufre just south of the Entrada Marabunda in January 2006 (Fig. 2; Pisarowicz 2005). For a comparison, cave mollies (males $N=10$; females $N=10$ ) also were collected in chamber V of the Cueva del Azufre during the same expedition (see Gordon and Rosen (1962) for a map of the Cueva del Azufre). Fish were sacrificed by overdose of MS222 and preserved on site in $10 \%$ formalin for later investigation.

Geometric morphometric analysis

Each specimen was photographed on a millimeter grid using a Nikon D70 digital camera. Because of distinct sexual dimorphism (male poecillids have a modified anal fin used for sperm transfer) males and females were analyzed separately. Thirteen landmarks were digitized on each specimen using tpsDig
Fig. 1 Cave mollies from the Luna Azufre (A): female, $38 \mathrm{~mm} \mathrm{SL}$; (B): male, $26 \mathrm{~mm}$ SL and the Cueva del Azufre (cave chamber V); (C): female: $38 \mathrm{~mm}$ SL; (D): male $28 \mathrm{~mm} \mathrm{SL}$
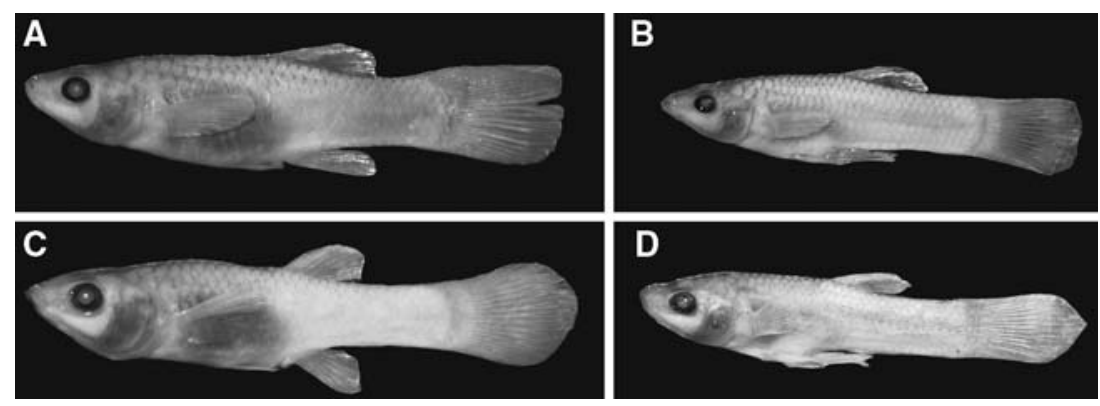
Fig. 2 Simplified map of the Luna Azufre after Pisarowicz (2005). Gray areas: creeks; arrows: direction of flow; sinuous lines: bat guano, dashes: slope

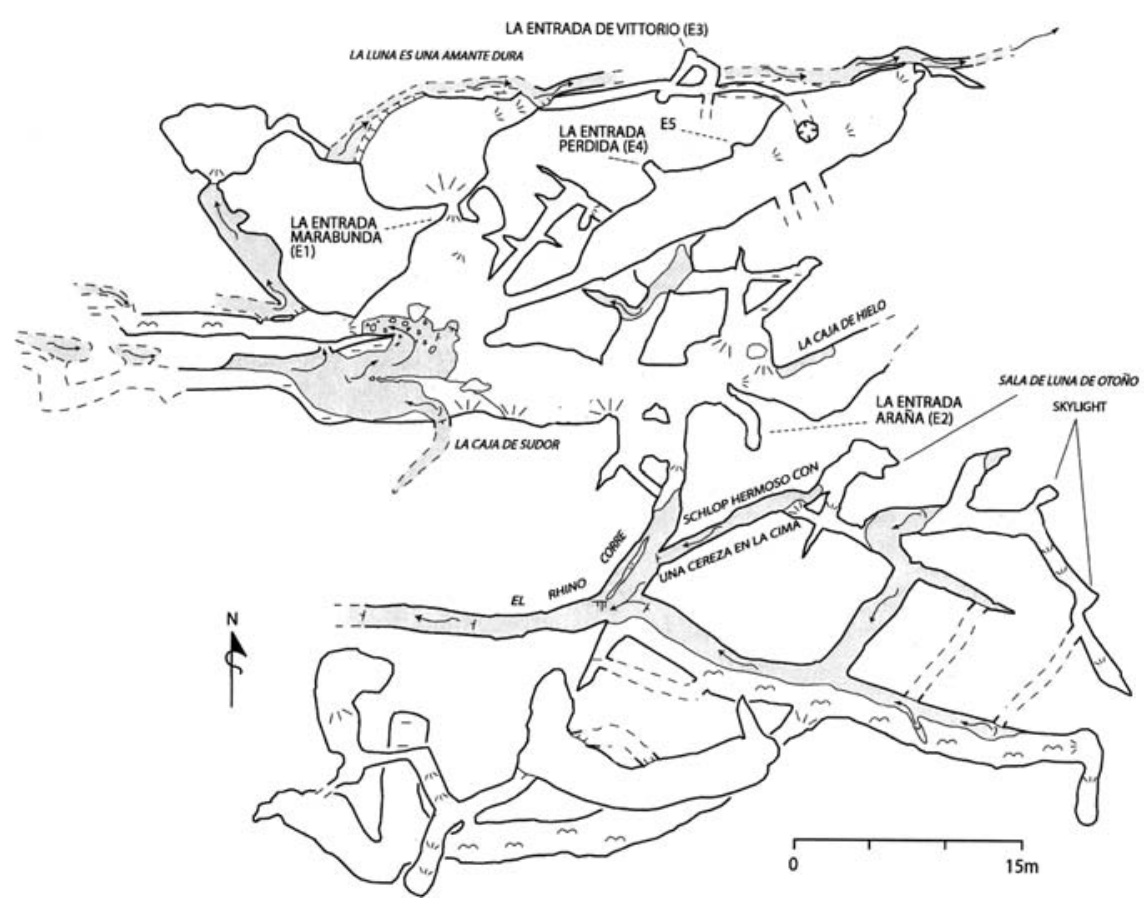

(Rohlf 2004): the tip of the upper jaw (1); the anterior (2) and posterior (3) margin of the eye; the anterior (4) and posterior (5) junction of the dorsal fin with the dorsal midline; the junction of the caudal fin with the dorsal (6) and ventral (7) midline; the anterior (8) and posterior (9) junction of the anal fin with the ventral midline; the anterior junction of the pelvic fins and the ventral midline (10); the bottom of the head where the operculum breaks away from the body outline (11); the upper end of the operculum where it connects to the body (12); and the dorsal junction of the left pectoral fin with the body (13).

Data were translated to NTS format using tpsUtil (Rohlf 2006). Subsequent analyses were performed using the thin-plate spline software tpsRegr (Rohlf 2005). Landmark coordinates were aligned using least-squares superimposition to remove effects of translation, rotation, and scale, and a consensus configuration was calculated. Cartesian transformation grids were generated illustrating the relative shape differences among populations. Furthermore, superimposed coordinates were subjected to a principal components analysis (PCA). Ten principal components, which accounted for $91.7 \%$ and $97.4 \%$ of the total shape variation in females and males, respectively, were included as dependent variables in a MANCOVA, in which 'population' was used as independent variable and 'centroid size' as a covariate to control for the effect of body size. The assumptions of normal distribution and homogeneities of variances and covariances were met for these analyses. Furthermore, discriminant function analysis was used to test whether individuals were correctly assigned to the population of origin.

\section{Color polymorphism}

Besides differences in shape we also investigated the distinct color polymorphism known from cave mollies in the Cueva del Azufre. Whereas the majority of the fish are pale, some show yellow coloration (Gordon and Rosen 1962; Parzefall 2001). We recorded the presence of both color morphs in the Luna Azufre and compared their relative frequencies to the Cueva del Azufre population using a $\chi^{2}$-test. Data for the Cueva del Azufre were collected during a survey in cave chambers III, IV, V, XI and XIII in August 2004.

\section{Length/weight relationship}

Cave mollies from the Cueva del Azufre also are reported to have an eminently lower body condition factor (i.e. a lower weight per given standard length) than populations from surface habitats (Plath et al. 
2005; Tobler et al. 2006), and their short-term survival is critically dependent on energy availability (Plath et al. submitted). We compared the length/ weight relationship between the two cave population using an ANCOVA with 'In(weight)' as dependent variable, 'population' and 'sex' as independent variables, and ' $\ln$ (standard length)' as covariate. The assumptions of normal distribution and homogeneity of variances were met.

\section{Environmental conditions}

Water parameters were measured using a Hydrolab Multisonde 4A (Hach Environmental). Measurements and calibration of probes were conducted according to the manufacturer's recommendations. Specific conductance was measured in $\mathrm{mS} \cdot \mathrm{cm}^{-1}$, dissolved oxygen in $\mathrm{mg} \cdot \mathrm{1}^{-1}$ and $\%$ saturation, and turbidity using a shuttered turbidity probe in nephelometric turbidity units [NTU].

For the determination of $\mathrm{H}_{2} \mathrm{~S}$ concentrations in the Luna Azufre, $1 \mathrm{ml}$ of water was injected into a vial containing $1 \mathrm{ml}$ of zinc acetate $(0.12 \mathrm{M}$ with $0.5 \mathrm{ml}$ $\mathrm{NaOH} 1.5 \mathrm{M}$ in a $\mathrm{N}_{2}$-atmosphere) using a syringe. The vials were stored at room temperature and photometric measurements were conducted later in the laboratory according to Cline (1969). To further check for the presence of $\mathrm{H}_{2} \mathrm{~S}$ in the Luna Azufre, $\mathrm{H}_{2} \mathrm{~S}$ was also measured in the air using an Industrial Scientific Gas Badge Pro ${ }^{\circledR}$.

\section{Results}

Geometric morphometric analyses

Both allometry (centroid size) and population identity had a significant effect on the shape variation among females of the two populations (Table 1A). The discriminant function analysis correctly assigned $100 \%$ of the specimens to the population of origin (see Table 2 for equality test of means). The consensus configuration and the Cartesian transformation grids for females are presented in Fig. 3A-C. By inspection of these grids, pronounced differences in body shape between females from the Luna Azufre and the Cueva del Azufre were found with a smaller head and a higher caudal peduncle in females from Luna Azufre.

The MANCOVA could not detect significant effects of allometry and population among males (Table 1B; likely this is an effect of the small sample size of $N=16$ ); the discriminant function analysis correctly assigned $87.5 \%$ of males to the population of origin, whereas two males from the Cueva del Azufre were misclassified to the Luna Azufre population (Table 2). The consensus configuration and the Cartesian transformation grids for males are shown in Fig. 3D-F. Although no significant differences could be detected between males from the different population, there is a trend of males from the Luna Azufre having smaller heads and a higher caudal peduncle as it was found in the females.

\section{Color polymorphism}

The distinct color polymorphism with pale and yellow morphs is not only present in cave mollies from the Cueva del Azufre, but also in the Luna Azufre population. The frequency of the yellow morph was significantly higher in the Luna Azufre population compared to the Cueva del Azufre population (Luna Azufre: 18 of 49 individuals yellow (37 $\%$ ); Cueva del Azufre: 21 of 391 individuals yellow (0.5\%; $\left.\chi^{2}: 53.03, P<0.001\right)$.

Table 1 Results of the MANCOVA on principal components depicting the shape variance of cave mollies of the Cueva del Azufre and the Luna Azufre

\begin{tabular}{|c|c|c|c|c|c|}
\hline \multicolumn{6}{|c|}{ A. Females $(N=36)$} \\
\hline Effect & $F$ & $d f_{\text {num }}$ & $d f_{\text {denom }}$ & $P$ & Estimated effect size \\
\hline Centroid size & 6.909 & 10 & 24 & $<0.001$ & 0.742 \\
\hline Population & 6.158 & 10 & 24 & $<0.001$ & 0.720 \\
\hline \multicolumn{6}{|c|}{ B. Males $(N=16)$} \\
\hline Effect & $F$ & $d f_{\text {num }}$ & $d f_{\text {denom }}$ & $P$ & Estimated effect size \\
\hline Centroid size & 2.901 & 10 & 4 & 0.158 & 0.879 \\
\hline Population & 1.575 & 10 & 4 & 0.351 & 0.798 \\
\hline
\end{tabular}


Table 2 Equality test of group means from the discriminant function analysis for the different coordinates (see materials and methods for a definition of coordinates)

\begin{tabular}{|c|c|c|c|c|c|c|}
\hline & \multicolumn{3}{|l|}{ Females } & \multicolumn{3}{|l|}{ Males } \\
\hline & Wilks' lambda & $F$ & $P$ & Wilks' lambda & $F$ & $P$ \\
\hline $\mathrm{X} 1$ & 0.769 & 10.208 & 0.003 & 0.942 & 0.860 & 0.369 \\
\hline Y1 & 0.811 & 7.918 & 0.008 & 0.954 & 0.678 & 0.424 \\
\hline $\mathrm{X} 2$ & 0.681 & 15.955 & 0.000 & 0.993 & 0.092 & 0.766 \\
\hline Y2 & 0.927 & 2.682 & 0.111 & 0.917 & 1.272 & 0.278 \\
\hline X3 & 1.000 & 0.016 & 0.901 & 1.000 & 0.007 & 0.936 \\
\hline Y3 & 0.963 & 1.319 & 0.259 & 0.993 & 0.094 & 0.764 \\
\hline $\mathrm{X} 4$ & 0.964 & 1.253 & 0.271 & 0.982 & 0.255 & 0.622 \\
\hline Y4 & 0.882 & 4.570 & 0.040 & 0.753 & 4.596 & 0.050 \\
\hline $\mathrm{X} 5$ & 0.882 & 4.560 & 0.040 & 0.963 & 0.533 & 0.478 \\
\hline Y5 & 0.944 & 2.018 & 0.165 & 0.822 & 3.031 & 0.104 \\
\hline X6 & 0.975 & 0.865 & 0.359 & 0.953 & 0.687 & 0.421 \\
\hline Y6 & 0.994 & 0.196 & 0.661 & 0.983 & 0.243 & 0.630 \\
\hline $\mathrm{X} 7$ & 0.942 & 2.074 & 0.159 & 0.851 & 2.460 & 0.139 \\
\hline Y7 & 0.745 & 11.630 & 0.002 & 0.807 & 3.356 & 0.088 \\
\hline X8 & 0.966 & 1.190 & 0.283 & 0.999 & 0.007 & 0.934 \\
\hline Y8 & 0.999 & 0.040 & 0.842 & 0.973 & 0.390 & 0.543 \\
\hline $\mathrm{X} 9$ & 0.980 & 0.687 & 0.413 & 1.000 & 0.001 & 0.982 \\
\hline Y9 & 0.971 & 1.006 & 0.323 & 0.980 & 0.283 & 0.603 \\
\hline X10 & 0.943 & 2.052 & 0.161 & 0.817 & 3.137 & 0.098 \\
\hline Y10 & 0.990 & 0.328 & 0.571 & 0.984 & 0.227 & 0.641 \\
\hline X11 & 0.701 & 14.519 & 0.001 & 0.964 & 0.518 & 0.484 \\
\hline Y11 & 0.921 & 2.924 & 0.096 & 0.996 & 0.054 & 0.820 \\
\hline $\mathrm{X} 12$ & 0.649 & 18.358 & 0.000 & 0.853 & 2.421 & 0.142 \\
\hline Y12 & 0.993 & 0.256 & 0.616 & 1.000 & 0.003 & 0.961 \\
\hline $\mathrm{X} 13$ & 0.882 & 4.529 & 0.041 & 0.998 & 0.024 & 0.879 \\
\hline Y13 & 0.942 & 2.079 & 0.158 & 0.998 & 0.032 & 0.861 \\
\hline
\end{tabular}

Fig. 3 Cartesian transformation grids showing the consensus configuration of all specimens examined (A): females; (D): males, and the relative shape differences between the consensus and the two populations (B): Luna Azufre females; $(\mathbf{C})$ : Cueva del Azufre females; (E): Luna Azufre males; (F): Cueva del Azufre males. Deformations are exaggerated three times
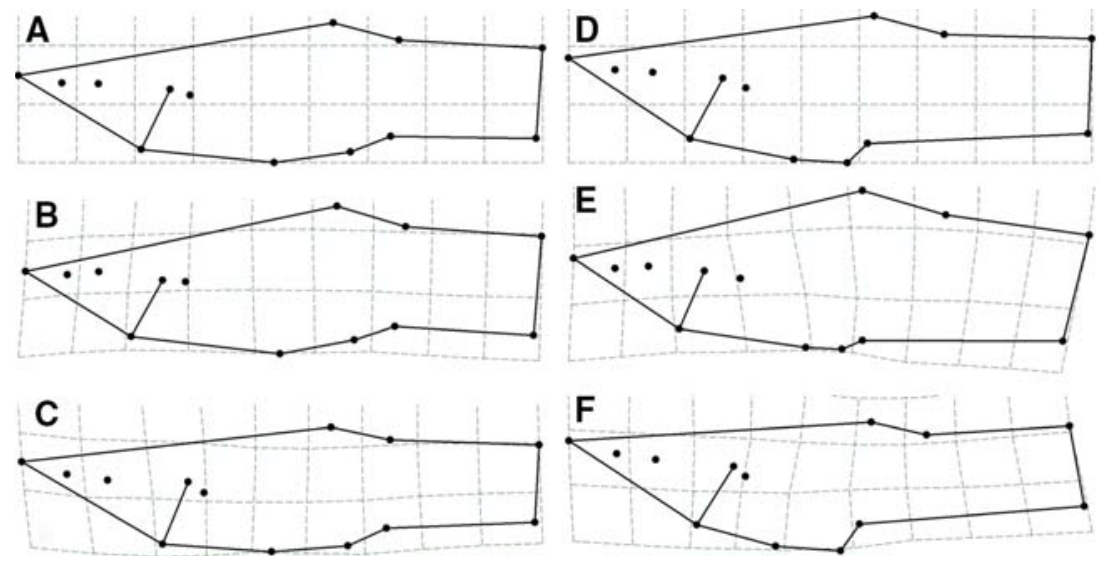
Length/weight relationship

As expected, there was a strong positive relationship between standard length and body weight (Fig. 4; $F=371.29, P<0.001$ ), but there were no differences between the two cave populations $(F=0.31$, $P=0.580)$. Males were significantly lighter than females $(F=12.87, P=0.001)$. The interaction term of 'population' and 'sex' was not significant $(F=0.52, P=0.474)$.

\section{Environmental conditions}

Measurements of the abiotic habitat characteristics in five different pools inside the Luna Azufre yielded the following results (mean $\pm \mathrm{SD}$ ): Temperature $27.5 \pm 4.3^{\circ} \mathrm{C}$, specific conductivity $3.613 \pm 1.255 \mathrm{mS}$, pH $7.1 \pm 0.0$, oxygen content $1.65 \pm 0.54 \mathrm{mg} \mathrm{l}^{-1}$ and relative oxygen saturation $22.0 \pm 7.7 \%$. The two $\mathrm{H}_{2} \mathrm{~S}$ samples taken revealed concentrations of $4 \mu \mathrm{M} \mathrm{H}_{2} \mathrm{~S}$ in a spring and $0 \mu \mathrm{M}$ in a stagnant pool south of the Entrada Marabunda. No hydrogen sulfide was detected in the air.

\section{Discussion}

The new population of cave mollies from the Luna Azufre described here is only the second cavernicolous population of a poeciliid fish known to date.

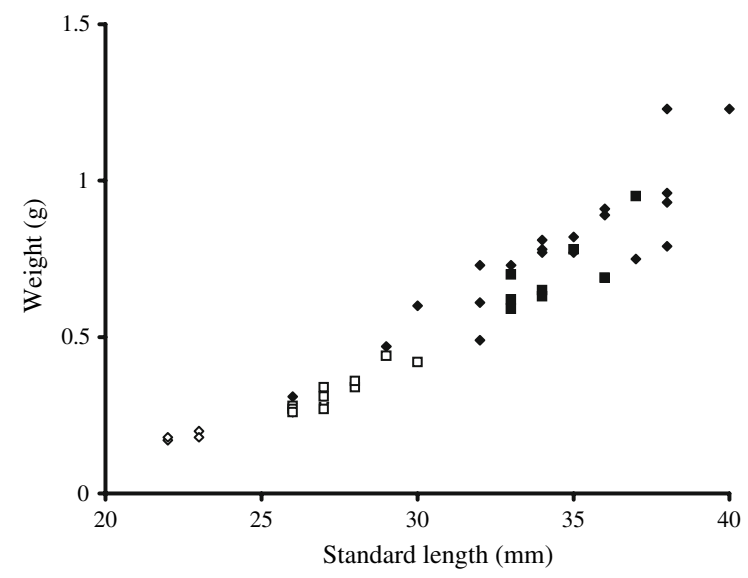

Fig. 4 Length/weight relationship in mollies from the Luna Azufre (males: $\diamond$; females: $\diamond$ ) and the Cueva del Azufre (males: $\square$; females:
Similarities in appearance between cave mollies from the Luna Azufre and the nearby Cueva del Azufre, are evident. Compared to surface populations, both cave populations have reduced eyes and reduced pigmentation (Gordon and Rosen 1962; Parzefall 2001). However, the geometric morphometric analysis revealed that the females of the new population are morphologically distinct from the population of the Cueva del Azufre in that individuals from the Luna Azufre have shorter heads and a higher caudal peduncle. The same trend, albeit not significant, was observed for the males. The biological significance of these traits is as yet unknown. The differences among the populations may be the result of phenotypic plasticity as suggested for other cave-dwelling organisms (see Romero and Green 2005 for a review).

The cave environment in the Luna Azufre differs from the Cueva del Azufre by the generally much lower $\mathrm{H}_{2} \mathrm{~S}$ concentrations. Inside the Cueva del Azufre, $\mathrm{H}_{2} \mathrm{~S}$ concentrations can reach more than $300 \mu \mathrm{M}$ (Tobler et al. 2006). This is also reflected by the low abundance of sulfur oxidizing bacteria in the Luna Azufre, which cover almost all wet surfaces in the Cueva del Azufre (Pisarowicz 2005; Tobler et al. personal observation). Caves are usually considered to be energy-poor habitats (Poulson and Lavoie 2000), but because of the presence of bacterial primary production and the input of bat guano, the Cueva el Azufre was suggested to be energy-rich even compared to surface habitats (Langecker et al. 1996). Bats and accumulations of bat guano can also be found in the Luna Azufre and likely provide the energy basis for the cave ecosystem.

Although the Cueva del Azufre is considered to be an energy-rich habitat, the mollies inhabiting the cave appear to be malnourished (Plath et al. 2005; Tobler et al. 2006) and energy availability affects the shortterm survival of the fish (Plath et al. submitted). It has been hypothesized that the low body condition is caused by costly adaptations necessary to cope with the high concentration of $\mathrm{H}_{2} \mathrm{~S}$ (Tobler et al. 2006; Plath et al. submitted). This idea is not supported by data on mollies from the Luna Azufre, where very low concentrations of $\mathrm{H}_{2} \mathrm{~S}$ were detected. Here, length/weight relationships did not differ significantly from that at Cueva del Azufre. This points to low energy availability in the Luna Azufre where chemoautotrophic primary production by sulfide-oxidizing bacteria likely plays an insignificant role. The 
effects of energy availability and the presence of $\mathrm{H}_{2} \mathrm{~S}$ on the body condition of cave mollies certainly warrant further investigations.

Both cave populations contain yellow morphs, but the frequency of the yellow morph differs significantly between the caves. This and the morphological differences observed indicate that the populations may be isolated. Although the caves are in close proximity, they are located within different hills that are separated by a surface valley. Previous research has shown that mollies from the Cueva del Azufre are reproductively isolated from the adjacent surface populations and that there is genetic structure even among mollies from different cave chambers within the Cueva del Azufre (Plath et al. 2007). Therefore it is unlikely that gene-flow between the Luna Azufre and the Cueva del Azufre populations exists; however population genetic analyses are needed to determine the extent of genetic isolation.

The cave molly system includes not only the two cave populations, but also closely related populations in adjacent surface habitats (sulfidic and non-sulfidic). This cluster of populations living under vastly different environmental conditions provides a unique system to study ecological diversification. The discovery of an additional cave population living in low-sulfide conditions is a keystone for future research on local adaptation and adaptive diversification in Poecilia mexicana.

Acknowledgments $\mathrm{We}$ are grateful to the people of Tapijulapa for their hospitality during our visits. K. Henker, N. Hines and V. Siegel kindly introduced us to the Luna Azufre. L. Krumholz helped in the lab and provided the infrastructure for sulfide measurements, T. J. DeWitt gave helpful advice for the geometric morphometric analysis, and M. Schartl as well as two reviewers provided useful comments on an earlier version of the manuscript. The Mexican government kindly issued a permit to conduct this research (Permiso de pesca de fomento number DGOPA/16988/191205/-8101). Financial support came from the University of Oklahoma, the DFG (SCHL 344/15-1; PL 470/11), the German Ichthyological Association (to M.T. and M.P) as well as the American Livebearer Association, the Basler Foundation for Biological Research, the Janggen-Poehn Foundation, the Roche Research Foundation, and the Wolfermann-Nägeli-Foundation (to M.T.).

\section{References}

Abdel-Latif H, Hassan E, von Campenhausen C (1990) Sensory performance of blind Mexican cave fish after destruction of the canal neuromasts. Naturwissenschaften 77:237-239
Bagarinao T (1992) Sulfide as an environmental factor and toxicant: tolerance and adaptations in aquatic organisms. Aquat Toxicol 24:21-62

Burt de Perera T (2004) Spatial parameters encoded in spatial map of the blind Mexican cave fish, Astyanax fasciatus. Anim Behav 68:291-295

Cline JD (1969) Spectrophotometric determination of hydrogen sulfide in natural waters. Limnol Oceanogr 14:454-458

Gordon MS, Rosen DE (1962) A cavernicolous form of the poeciliid fish Poecilia sphenops from Tabasco, México. Copeia 1962:360-368

Grieshaber MK, Völkel S (1998) Animal adaptations for tolerance and exploitation of poisonous sulfide. Ann Rev Physiol 60:33-53

Jeffery WR (2005) Adaptive evolution of eye degeneration in the Mexican blind cavefish. J Heredity 96:185-196

Körner KE, Schlupp I, Plath M, Loew ER (2006) Spectral sensitivity of mollies: comparing surface- and cavedwelling Atlantic mollies, Poecilia mexicana. J Fish Biol 69:54-65

Langecker TG, Wilkens H, Parzefall J (1996) Studies on the trophic structure of an energy-rich Mexican cave (Cueva de las Sardinas) containing sulfurous water. Mémoires de Biospéologie 23:121-125

Miller RR (2005) Freshwater fishes of Mexico. University of Chicago Press, Chicago

Parzefall J (1970) Morphologische Untersuchungen an einer Höhlenform von Mollienesia sphenops (Pisces, Poeciliidae). Zeitschrift für Morphologie der Tiere 68:323-342

Parzefall J (1973) Attraction and sexual cycle of poeciliids. In: Schroeder J (ed) Genetics and mutagenesis of fish, Springer Verlag, Berlin, pp 177-183

Parzefall J (1993) Behavioural ecology of cave-dwelling fishes. In: Pitcher TJ (ed) Behaviour of teleost fishes, 2nd edn. Chapman and Hall, London, pp 573-608

Parzefall J (2001) A review of morphological and behavioural changes in the cave molly, Poecilia mexicana, from Tabasco, Mexico. Environ Biol Fishes 62:263-275

Peters N, Peters G, Parzefall J, Wilkens H (1973) Über degenerative und konstruktive Merkmale bei einer phylogenetisch jungen Höhlenform von Poecilia sphenops (Pisces, Poeciliidae). Internationale Revue der Gesamten Hydrobiologie 58:417-436

Pisarowicz J (2005) Return to Tabasco. Assoc Mexican Cave Studies Newslett 28:27-57

Plath M, Hauswaldt JS, Moll K, Tobler M, García de León FJ, Schlupp I, Tiedemann R (2007) Local adaptation and pronounced genetic differentiation in an extremophile fish, Poecilia mexicana, inhabiting a Mexican cave with toxic hydrogen sulfide. Mol Ecol 16:967-976

Plath M, Heubel KU, García de León FJ, Schlupp I (2005) Cave molly females (Poecilia mexicana, Poeciliidae, Teleostei) like well-fed males. Behav Ecol Sociobiol 58:144-151

Plath M, Parzefall J, Körner KE, Schlupp I (2004) Sexual selection in darkness? Female mating preferences in surface- and cave-dwelling Atlantic mollies, Poecilia mexicana (Poeciliidae, Teleostei). Behav Ecol Sociobiol 55:596-601

Plath M, Parzefall J, Schlupp I (2003) The role of sexual harassment in cave- and surface-dwelling populations of 
the Atlantic molly, Poecilia mexicana (Poeciliidae, Teleostei). Behav Ecol Sociobiol 54:303-309

Poulson TL (1963) Cave adaptation in amblyopsid fishes. Am Midland Naturalist 70:257-290

Poulson TL, Lavoie KH (2000) The trophic basis of subterranean ecosystems. In: Wilkens H, Culver DC, Humphries WF (ed) Ecosystems of the world 30: subterranean ecosystems, Elsevier Science, Amsterdam, pp 231-249

Proudlove G (2006) An account of the subterranean (hypogean) fishes described up to 2003 with a bibliography 1541-2004. International Society for Subterranean Biology, Moulis

Rohlf F (2004) tpsDig. Available from http://life.bio. sunysb.edu/morph/

Rohlf F (2005) tpsRegr. Available from http://life.bio. sunysb.edu/morph/

Rohlf F (2006) tpsUtil. Available from http://life.bio. sunysb.edu/morph/

Romero A, Green SM (2005) The end of regressive evolution: examining and interpreting the evidence from cave fishes. J Fish Biol 67:3-31
Strecker U, Bernatchez L, Wilkens H (2003) Genetic divergence between cave and surface populations of Astyanax in Mexico (Characidae, Teleostei). Mol Ecol 12:699-710

Tobler M, Schlupp I, Heubel KU, Riesch R, García de León FJ, Giere O, Plath M (2006) Life on the edge: Hydrogen sulfide and the fish communities of a Mexican cave and surrounding waters. Extremophiles 10:577-585

Walters L, Walters V (1965) Laboratory observations on a cavernicolous poeciliid from Tabasco, Mexico. Copeia 1965:214-233

Wilkens H, Strecker U (2003) Convergent evolution of the cavefish Astyanax (Characidae, Teleostei): genetic evidence from reduced eye-size and pigmentation. Biol J Linnean Soc 80:545-554

Zeiske E (1968) Prädispositionen bei Mollienesia sphenops (Pisces, Poeciliidae) für einen Übergang zum Leben in subterranen Gewässern. Z Vgl Physiol 58:190-222 